\title{
Magas rizikófaktorú deviáns-veszélyeztetett fiatalok iskolai kötődései
}

\author{
Nász Barbara \\ Eszterházy Károly Főiskola, Neveléstudományi Doktori Iskola, PhD-hallgató
}

\begin{abstract}
A kötődés alapvetöen az anya és a gyermek kapcsolatának ismérveit feltáró viselkedéses rendszer, melyet Jonh Bowlby definiált a hatvanas évek végén. Azóta a kötődés már nem csak ebben a klasszikus viszonyrendszerben értelmezhető: számos alterülete bontakozott ki, melyek közül az egyik, napjainkban igen nagy jelentőséggel bíró, az iskolai kötődés. Az alábbi tanulmányban egy magas rizikófaktorú deviáns-veszélyeztetett fiatalok kötődésvizsgálatával foglalkozó pilotkutatás második része kerül bemutatásra. A vizsgálat során deviáns-veszélyeztetett és nem veszélyeztetett fiatalok iskolához füződő kötődéserőssége került feltárásra, kérdőíves módszerrel. A kutatás fókuszában voltaképpen az állt, hogy megjelenhet-e az iskola másodlagos, illetve pótkötődési tárgyként a fiatalok esetében, hatványozva ezzel védőfaktor-funkcióját.

A tanulmány első felében a normától való eltérés ismérvei és annak következményei, a többszörös kötődés Bowlby-féle elképzelése, illetve az iskolai kötődés különböző aspektusai kerülnek bemutatásra. A második részben pedig az empirikus vizsgálat eredményei olvashatóak, külön hangsúlyt fektetve az iskolai kötődés intenzitásának különbségeire, a tanárokhoz füződő viszony analízisére, illetve, a korábbi vizsgálati eredmények összefüzésével, az iskolai és az anyai kötődés koherenciájára.
\end{abstract}

Kulcsszavak: iskolai kötődés, kötődéserősség, deviáns-veszélyeztetett fiatalok, másodlagos kötődési tárgy, pót-kötődési tárgy

Az iskolai kötődés kérdésköre a nemzetközi szakirodalom palettáján már régóta jelen van, s a hazai kutatások is egyre szélesebb körben foglalkoznak a témával. Számos vizsgálat bizonyítja, hogy az iskolához fúződő pozitív viszony nagy szerepet játszik a deviáns, illetve egészségkárosító magatartás megelőzésében is (Szabó és Virányi, 2011). A vizsgálat során pontosan ez a kérdés állt a középpontban: míg egy korábbi számban a magas rizikófaktorú deviáns-veszélyeztetett és nem veszélyeztetett fiatalok anyai kötődéserősség-vizsgálatának eredményei kerültek bemutatásra, addig a pilotkutatás második része az iskolához füződő kötődés erősségét, illetve az anyai és az iskolai kötődés korrelációit helyezi fókuszba, ugyanazon célcsoport esetében.

\section{Normától való eltérés}

A deviancia olyan viselkedésformát jelöl, amely eltér a társadalom által elfogadottnak vélt normáktól, azonban mindig csak a megfelelő szociokulturális kontextusban értelmezhető, hiszen az abszolút norma, melyet minden társadalom elfogadottnak tekintene, nem létezik (Pikó, 2002). Ebből a tézisből fakadóan a deviáns viselkedés megnyilvánulási formái különbözőek lehetnek. Harcsa és Andorka (1990) a leggyakoribbakat igyekezett felsorolni tanulmányukban, melyek az alábbiak: alkoholizmus, bűnözés, öngyilkosság és a mentális betegségek.

A normától való eltérő magatartás kialakulásában számos tényező játszik közre: a biológiai, genetikai összetevők mellett a pszichikai faktor is kiemelkedő jelentőséggel bír. Mindemellett a család szerepe is különösen fontos a deviáns viselkedés kialakulását illetően, hiszen elsődleges szocializációs térként tartjuk számon ezt a közösséget, 
s az általa közvetített értékek, normák átörökítődnek a fiatalabb generációk tagjaira. A család optimális esetben egy érzelmi közösség, s ilyen formában védőhálóként van jelen az ember életében.

Amennyiben a család valamilyen oknál fogva nem tölti be funkcióját, vagyis nem nyújt a gyermeknek humán értékeket, akkor a gyermek nem fogja fontosnak érezni a családi köteléket sem, s máshol fog kötődési pontokat keresni. Ilyen családon kívüli kötődési pontok lehetnek, elsősorban a hasonló társadalmi helyzetű kortárs csoportok is (Kisida, 1999 idézi Nász, 2015). Ezekben az esetekben a család tradicionális funkcióvesztése mellett a védőfaktor szerepe is megszünik, s a mintakövetés következtében fennálló reprodukciós lehetőségek miatt inkább rizikófaktorként jelenhet meg a gyermek életében.

Lehetséges kötődési tárgyként tekinthetünk az iskolára, s itt nemcsak az intézményhez, tárgyakhoz és a kortársakhoz, hanem a pedagógusokhoz füződő viszony is kiemelt jelentőségű lehet. A családi kötődés hiányát ellensúlyozva, védőfaktorként jelenhet meg a tanárokhoz való kötődés (Nász, 2015).

\section{Bowlby és a többszörös kötődés}

Bowlby nagy hangsúlyt fektet a többszörös kötődés elméletére, melynek legmarkánsabb jellemzőit az alábbiakban foglalom össze.

Bowlby azt feltételezte, hogy a gyermek életében nemcsak egyetlen kötődési figura létezhet. Több empirikus vizsgálat is azt bizonyítja, hogy nemcsak az elsődleges gondozó, tehát leggyakoribb esetben az anya, hanem az apa, a nagyszülők, vagy az idősebb testvérek is lehetnek kötődési személyek (Inántsy-Papp, 2008).

A lehetséges kötődési személyek száma tehát nem maximalizálható egy föben, azonban mindenképp le kell szögezni, hogy nem lehet végtelen számú sem (Cassidy, 1999).

A kötődési személyeknek szigorú hierarchiájuk van. Itt vezeti be Bowlby a monotrópia kifejezést, amely az elsődleges kötődési figura preferenciáját jelenti. Bowlby azzal magyarázza ezt a jelenséget, hogy ha a gyerekek nem a hierarchia élén álló, elsődleges kötődési személyhez fordulnának igényeik kielégítése céljából, feltehetően sokkal gyakrabban ütköznének elutasításba (Bowlby, 2009).

A kötődési hierarchia kialakulásában kiemelt szerepe lehet az alábbi tényezőknek: mennyi időt tölt az adott személlyel a gyermek; a gondoskodás minősége, amelyet az adott személyek nyújtanak; az emocionális befektetések a gyermek irányába; a szociális jelzések használata (Colin, 1996 idézi Inántsy-Papp, 2009).

Ahogyan a fönt említett tanulmányok és vizsgálatok bizonyítják, több személy is válhat kötődési személlyé a gyermek életében. Ilyen potenciális kötődési személy lehet például a pedagógus is, ahogyan korábban már utaltam erre. Természetesen a gyermek és a pedagógus között létrejövő kötődés nem azonos az anya és gyermek közötti kötődési kapcsolattal, hiszen itt más preferenciák mérvadóak.

A kutatások a kapcsolat szorosságát emelik ki, amely a melegséget és a nyílt kommunikációt jelenti. A kapcsolat szorossága a gyermek részéről azt jelenti, hogy mennyire érzi magát biztonságban a tanára mellett, illetve számíthat-e a védelmére, támogatására. A pedagógus oldaláról pedig az érzékenységet hangsúlyozza, amely a gyermek igényeire történő megfelelő reakciót jelenti (F. Lassú, 2011).

Egy iskolai előkészítőben végzett vizsgálat eredményei szerint, amennyiben a pedagógus megfelelően érzékenyen reagált, úgy képes volt a kötődési zavarok átvitelét megakadályozni a pedagógus-gyermek kapcsolatot illetően, ezáltal a gyermek belső munkamodelljének átprogramozására. Fontos szem előtt tartani azonban, hogy 
a pedagógus személye csak akkor hathat védőfaktorként a gyermekre, ha nem általánosságban, hanem konkrétan az adott gyermekre irányul az érzékenység, a személyes figyelem ( $F$. Lassú, 2011).

Az óvodában és az az iskolában sem feltétlenül csak a pedagógushoz kötődhet a gyermek, hanem a kortársakhoz, az iskolai környezethez, tantárgyakhoz egyaránt. Az iskolához való kötődés egy komplex érzelmi kapcsolat, mely kialakulásának magyarázatára többféle álláspont létezik. A szociális kontrollelmélet a deviancia dimenziójából közelít az iskolai kötődés magyarázatához. Az alábbiakban az elképzelés részleteit mutatom be.

\section{Az iskolai kötődés aspektusai}

A tankötelezettség következtében a gyerekek idejük nagy részét az iskolában töltik. $A z$ iskolához való viszony minden gyermek estében egyaránt lehet pozitív vagy negatív. Az egyéni tapasztalatok összessége határozza meg a kapcsolat minőségét.

Az iskolában eltöltött idő alatt ebből a kezdeti attitűdből kialakulhat egy magasabb érzelmi kapcsolat, vagyis az iskolai kötődés, aminek mértéke azzal mutat összefüggést, hogy a gyerekek mennyire elégedettek az iskolával és hogyan reagálnak az őket ért hatásokra (Hill és Werner, 2006 idézi Szabó és Virányi, 2011).

A szociális kontrollelmélet - mely Hirschi nevéhez füződik - két faktort különböztet meg az iskolai kötődésen belül, mely faktorok a következők: iskolához való kötődés és a személyhez való kötődés, amely tulajdonképpen a személy és az intézmény irányába táplált pozitív érzéseket, pozitív viszonyulást jelenti. Minél pozitívabb érzésekről esik szó, annál inkább kötődni fog az egyén (Hirschi, 1969).

A kontrollelméletet a deviancia aspektusából is meg lehet közelíteni. E szerint a deviáns viselkedés akkor jelenik meg, ha az egyén társadalomhoz - családhoz, iskolához, közösségi csoportokhoz - való viszonya instabil, gyenge vagy megszakad (Hirshi, 1969).

Így tulajdonképpen azt mondhatjuk, hogy az iskolával való pozitív viszony kialakítása, tehát az iskolához való kötődés, védőfaktorként szolgálhat a deviánsveszélyeztetett gyerekek számára.

Hirshi elméletét kiszélesítve az érzelmek hangsúlyozása is kiemelkedően fontos. Az iskolai kötődés egy olyan érzelmi állapot, amely során a gyermek azonosul az iskolájával és annak részének érzi magát, megtalálja helyét benne, és közösségi kapcsolatokat alakít ki az intézményen belül (Moody és Bearman, 1998 idézi Szabó és Virányi, 2011).

Az iskolai kötődés, ahogy föntebb már említettem, rendkívül fontos lehet a deviáns viselkedés megelőzésében. Ezen kívül természetesen a tanulmányi előmenetelt illetően, illetve a személyiségformáló hatását tekintve is pozitív összefüggés tárható föl (Szabó és Virányi, 2011). A kutatást alapvetően ez a kérdés motiválta, vagyis, hogy milyen összefüggésben állhat az iskolához füződő kapcsolat és a deviáns veszélyeztetettség. A kutatás részletei, illetve az eredmények a következőkben kerülnek bemutatásra.

\section{Az empirikus vizsgálat jellemzői}

\section{Célok és hipotézisek}

A vizsgálat egy két részből álló pilotkutatás, melynek fókuszában a deviáns-veszélyeztetett és nem veszélyeztetett fiatalok kötődésintenzitásának vizsgálata áll. A kutatás első része, mely a lap 2015-ös első számában olvasható az anyához való kötődés 
erősségének elemzését álítja középpontba ${ }^{1}$, míg a második rész, melynek eredményei alább olvashatóak, az iskolához, pedagógusokhoz való kötődésre és annak ismérveire fókuszál. A vizsgálattal tulajdonképpen arra kerestem a választ, hogy az iskola funkcionálhat-e másodlagos, illetve pót-kötődési tárgyként a veszélyeztetett, illetve a nem veszélyeztetett csoportokat illetően. A kutatást megelőzően az alábbi hipotéziseket állítottam föl:

1. A vizsgálati csoport tagjait szorosabb viszony füzi az iskolához, tehát az iskolához való kötődésük intenzitásában eltérést mutatnak a kontrollcsoportéhoz képest.

2. A vizsgálati csoport magasabb értéket ér el a tanárokhoz való viszonyt mérő faktoroknál, mint a kontrollcsoport, tehát szorosabb viszony füzi őket tanáraikhoz.

3. A deviáns-veszélyeztetettség és az iskolához való kötődés erőssége között pozitív összefüggés van, nemcsak a csoport, hanem az egyén szintjén is. Tehát minél inkább veszélyeztetett az egyén, annál erősebben fog kötődni az iskolához.

4. Az anyához és az iskolához való kötődés pozitív összefüggést mutat.

\section{A kutatási minta bemutatása}

A kutatásban összesen 94-en vettek részt. A vizsgálati csoportban az édesanya iskolai végzettségét tekintve 53 tanuló esetében a legmagasabb végzettség, legfeljebb 8 általános. Egy tanuló esetében az anya legmagasabb iskolai végzettsége középfokú szakképzettség.

A kontrollcsoportban résztvevő tanulók közül 16 tanulónál az édesanya legmagasabb iskolai végzettsége az érettségi, míg 16 tanuló esetében a főiskolai diploma, szintén 16 tanuló esetében pedig egyetemi diploma. Az adott kérdéskörben két hiányzó adat szerepel.

\begin{tabular}{|l|c|c|c|}
\hline \multicolumn{1}{|c|}{ Nem } & Kontrollcsoport & Vizsgálati csoport & Összesen \\
\hline Fiú & 15 & 32 & 47 \\
\hline Lány & 25 & 22 & 47 \\
\hline Összesen & 40 & 54 & 94 \\
\hline
\end{tabular}

1. táblázat: A kutatásban részt vevők száma nemek szerinti bontásban

\section{A kutatás módszere}

Az iskolai kötődés vizsgálatához Szabó Éva és Virányi Barbara (2011) által kidolgozott Iskolai kötődés kérdőívet használtam.

A kérdőív jellegzetességeiből adódóan a kapott eredmények kvantitatívak, vagyis számszerüsíthetőek, tehát lehetőséget kínálnak az adatok statisztikai elemzésére.

A kutatást egy-egy adott intézmény felső tagozatos tanulóin végeztem el, a kiválasztás tehát leginkább önkényes mintavételnek tekinthető, ezért a teljes sokaságra nézve a vizsgálati eredmények nem reprezentatívak.

\section{Az Iskolai kötődés kérdöív bemutatása}

A teszt alapvetően abból a hipotézisből indul ki, hogy az iskolai kötődést a személyes kapcsolatok, a tantárgyakhoz és a környezethez való viszony határozza meg. Ennek

\footnotetext{
1 Nász Barbara (2015): A deviáns veszélyeztetettség és az anyai kötődés kapcsolata. Gyermeknevelés, 3. 2. sz. 15-28.
} 
alapján összesen öt faktort mér, melyek a következők: Az iskolai viszony, pl.: Több olyan nap van, amikor szívesen jövök iskolába, mint amikor nem. A társakhoz való viszony, pl.: Sok barátom van az iskolában. A tanárokhoz való viszony, pl.: Több olyan tanárom van, akit kedvelek, mint akit nem. A tantárgyak iránti érdeklődés, pl.: Kevés érdekes tantárgyat tanulunk. Végül pedig az iskolai környezethez való viszony, pl.: Szeretem az iskolám udvarát, van hely játékra és pihenésre is. A kérdőív négyfokú Likert-skálát használ, a válaszadóknak az „egyáltalán nem jellemző rám” és a „teljesen jellemző rám" választó kategóriák között kell dönteniük.

A teszt különböző komponensei között erős együttjárás tapasztalható, ez arra utal, hogy a jelenség nem egydimenziós, hanem több tényező együttesen határozza meg a kötődés irányát és intenzitását. $A z$ iskolához való viszony interkorrelációt mutat valamennyi alfaktorral. A korrelációs erősségek alapján a legerősebb kapcsolat a tantárgyakkal való viszonnyal áll fönn, ezt követi a tanárokhoz való viszony, az iskolai környezethez való viszony és a leggyengébb kapcsolat a kortársakhoz való viszony alfaktora (Szabó és Virányi, 2011).

\section{A kutatás menete}

A vizsgálat 2014 novemberétől és 2015 januárjáig tartott. A vizsgálati csoport tagjai egy dél-hevesi kistelepülés általános iskolájának felső tagozatos tanulói. A település része Heves megye leghátrányosabb régiójának. A falu lakóinak száma közel 1526 fő. A gyermekkorúak aránya igen magas, a Központi Statisztikai Hivatal adatai szerint 444 a 0-17 évesek száma a faluban a munkanélküliek, illetve az inaktív keresők száma a községben megközelíti az 50 százalékot ( $K S H, 2011)$.

Az iskola, ahol a vizsgálat zajlott, egy állami fenntartású intézmény, ahová közel 120 gyermek jár. (A településen az állami iskolán kívül található még egy egyház által müködtetett általános iskola is.) A tanulók kivétel nélkül hátrányos helyzetủek, de igen magas a halmozottan hátrányos helyzetü gyerekek aránya is.

A kontrollcsoport tagja ezzel szemben nem faluban élő, hanem városi diákok voltak. A megyeszékhely egyik általános iskolájának, találomra kiválasztott felsős tanulói vettek részt a vizsgálatban.

\section{A vizsgálat eredményei}

\section{Különbségek az iskolához való kötődés intenzitása között}

Az alapvető hipotézisem az volt, hogy az iskolai kötődést illetően a két csoport között jelentős eltérés mutatható ki. Azt feltételeztem, hogy a vizsgálati csoport tagjait szorosabb viszony fúzi az iskolához, mint a kontrollcsoport tagjait.

A feltételezésemet az alábbi analógiára füztem föl: Az iskola kiemelt fontosságú szociális tér, a gyerekek itt találkoznak egymással, itt tapasztalnak meg olyan interakciókat, amelyekre otthon a családi környezetben egyszerüen nincs lehetőség. Természetesen nem csak az iskola ad erre kiváló terepet, hanem különböző iskolán kívüli elfoglaltságok: sportegyesület, zeneiskola, tánccsoport és rengeteg egyéb lehetőség. Egy halmozottan hátrányos helyzetü gyereknek, aki egy szintén hátrányos helyzetű régióban él talán kevesebb lehetősége van az iskolán kívül más elfoglaltságot üzni. A legtöbb gyereknek, akik a vizsgálati csoport tagjai, az iskola az egyetlen tér, ami különbözik az otthontól. Itt lehetnek kortársak között, itt gyakorolhatják a különböző viselkedésmintákat. Azt gondolom, ezért az ő kötődésük alapvetően szorosabb, mint a kontrollcsoport tagjaié. 
A kérdőívre adott válaszok a számok tükrében az alábbiak szerint alakultak:

- Az iskolai kötődés összesített pontszámainál a szórását illetően F-próbával megállapítható, hogy nincs a két csoport között szignifikáns eltérés, ezért az átlagok elemzéséhez megalapozott a kétmintás t-próba használata.

- A vizsgálati csoport esetében a pontszámok átlaga 64,87, ehhez képest a kontrollcsoportnál 56,53. Az átlagok eltérésének statisztikai ellenőrzéséhez a t-eloszlás kritikus értéke 95\%-os szignifikancia szinten, 85-ös szabadságfok mellett 1,99. A t-próba értéke az összesített pontszámok esetében 4,47. Így a vizsgálati és a kontrollcsoport között szignifikáns különbség figyelhető meg.

Az Iskolai kötődés kérdőívet kiértékelve azt a megállapítást tehetem, hogy a vizsgálati csoport iskolához való kötődése alapján tényleges, szignifikáns különbséget mutat a kontrollcsoporthoz képest, tehát a hipotézisem, miszerint a vizsgálati csoport tagjait szorosabb viszony füzi az iskolához elfogadottnak tekinthető.

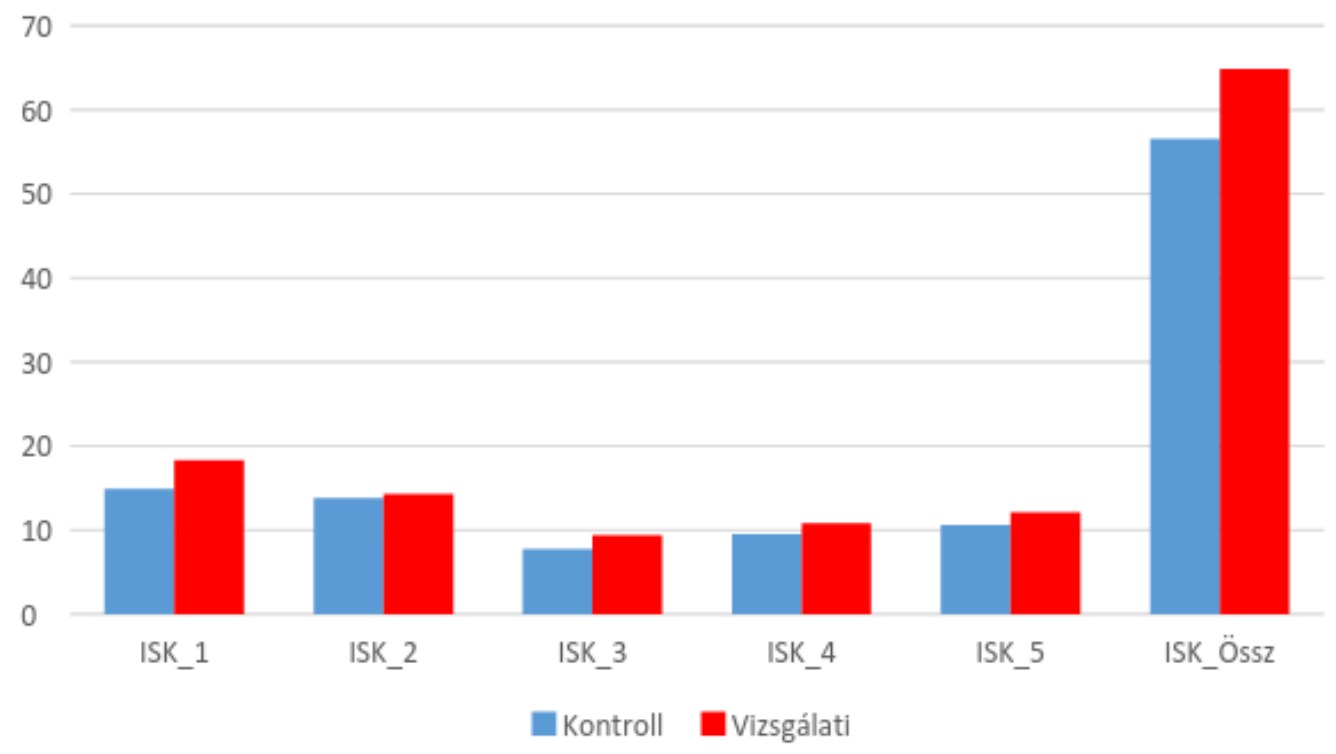

1. ábra: Iskolai kötődés pontszámainak átlaga csoportonként, faktoronkénti bontásban

A szorosabb kötődés hátterében meghúzódhat - a korábban már említett - az iskola szocializációs funkciója. Másrészt az iskola biztonságot, kiszámíthatóságot jelent. Egy olyan családban, ahol a szülők nem rendelkeznek munkahellyel, nincs ehhez kapcsolódó megszokott napi rutin, nincs rendszeres jövedelem, az alapvető létbizonytalanság mint általános életérzés jelenhet meg. Ezzel szemben az iskolában minden rutinszerüen, rendezetten, kiszámíthatóan folyik. Bowlby szerint a kötődés tulajdonképpen nem más, mint a biztonságos bázis elérésére való törekvés. A vizsgálati csoport gyerekei számára az iskola betöltheti ezt a funkciót.

Ha ez a bizalmi kapcsolat létrejön a gyermek és az iskola között, akkor az iskola részéről jövő társas támogatás, a kontrolling és a monitoring jelenléte szorosabbá teheti a két fél közötti kapcsolatot, így válhat az iskola jelentős védőfaktorrá a gyermek életében a deviáns veszélyeztetettség megelőzésében.

\section{Kötődés a tanárokhoz}

Azt feltételeztem, hogy a vizsgálati csoport magasabb értéket fog elérni a tanárokhoz füződő kapcsolatot vizsgáló faktort illetően, tehát tagjai jobban kötődnek a tanárokhoz, mint a kontrollcsoport tagjai. 
A hipotézisemet elsősorban a többszörös kötődés elképzelésre alapoztam. Bowlby szerint a gyermek nem csak egy személyhez kötődhet. A lehetséges kötődési személyek között a pedagógusok is előkelő helyen szerepelhetnek, hiszen elég sok időt töltenek a gyerekekkel. Ez a kiindulási alap azonban épp úgy érvényes lenne a kontrollcsoport tagjaira is. Így feltétlenül ki kell egészítenem a gondolatmenetet a biztos bázis elképzeléssel. A vizsgálati csoport tagjainak életkörülményei nem kifejezetten kiszámíthatóak, sőt a napról napra történő változás, bizonytalanság jellemzi. Például egy költözés, ami iskolaváltással is jár, náluk gyakran megtörténhet. Ez a kiszolgáltatottság eredményezheti azt, hogy biztos bázist keresnek maguknak, akár a családon kívül is.

Azt gondolom tehát, hogy nagyobb eséllyel töltheti be a másodlagos kötődési személy funkcióját a pedagógus a vizsgálati csoport tagjainak esetében.

A pedagógusokkal létrejött kapcsolatot vizsgáló faktorra adott válaszok az alábbiakban olvashatóak:

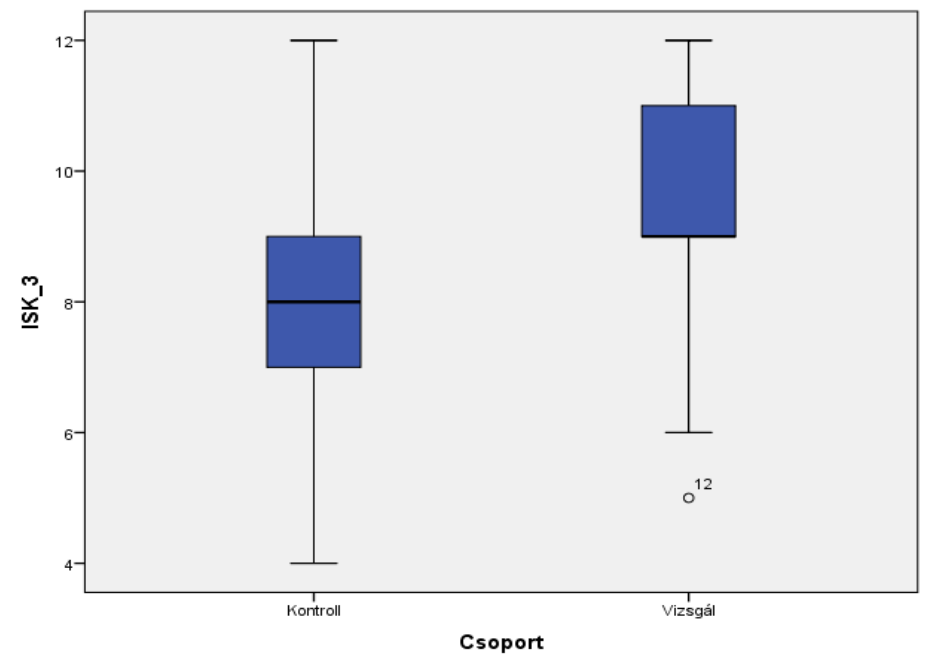

2. ábra: A pedagógusokhoz való viszony faktorra adott pontszámok csoportonként

A szórást illetően nem beszélhetünk jelentős különbségröl (a vizsgálati csoportnál 1,78, míg a kontrollcsoportnál 1,86), az átlag viszont jelentős eltérést mutat: a vizsgálati csoportnál 9,36 míg a kontrollcsoportnál 7,73, mely az elvégzett t-próba ismeretében szignifikánsnak tekinthető.

Ezek alapján azt a megállapítást tehetem, hogy a két csoport tanárokhoz való kötődés kérdéscsoportra adott válaszai szignifikáns eltérést mutattak, tehát a hipotézisem beigazolódott.

Azt gondolom, hogy ez a bizonyosság azt jelenti, hogy a pedagógusoknak valóban lehetőségük van arra, hogy a gyerekekben kialakult belső munkamodellt, - ami a kötődési kapcsolatok alapvető meghatározója - megfelelő érzékenységgel, a gyermek felé mutatott nyitottsággal pozitív irányba programozzák.

\section{A deviáns-veszélyeztetettség és az iskolai kötődés összefüggései}

A vizsgálat során alapvetően a csoportok közötti eltérésekre és hasonlóságokra fókuszáltam, egységben kezelve a válaszokat. Az egyéni különbségeket nem hangsúlyoztam, hiszen nem voltak relevánsak a kutatás eddig bemutatott perspektívájából. Azonban a deviáns veszélyeztetettség és az iskolai kötődés keresztmetszetét tekintve az egyéni differenciák is hangsúlyosak lehetnek. 
Az egyén és a csoport közötti eltérés hátterében több releváns indok húzódhat meg. Feltételezhető, - többek között - hogy a csoportdinamikai történések közül a csoportnyomás hatása kifejezetten magas, adott esetben. Az okok tényleges feltárásához azonban komplexebb kutatásra lenne szükség. Az azonban leszögezhető, hogy nem a deviáns veszélyeztetettség az oka a magasabb iskolai kötődésnek, hanem valami más. A két csoport ismérveit illetően egészen sok alapvető jellemzőben mutattak egymáshoz képest eltérést. A vizsgálati csoport tagjai egy kis településen élnek, kevesebb gyerek jár az iskolába, kevesebb pedagógus tanítja őket, de a szülők iskolai végzettségét tekintve is jelentős különbség állapítható meg a két csoport között. Elképzelhető, hogy ez a faktor is hozzájárul akár közvetlenül vagy közvetve ehhez az eredményhez. Ahhoz azonban, hogy ez ne csak feltételezés maradjon összetettebb vizsgálódásra lenne szükség.

Alapvetően azt a fontos konzekvenciát szürhetjük le, hogy míg a veszélyeztetett csoportokról általánosságban elmondható, hogy szoros viszony füzi őket az iskolához, addig az nem állapítható meg, hogy ilyen csoporton belül a veszélyeztetettség növekedésével az iskolához való kötődés is erősebb lenne. Tehát a hipotézisem nem igazolható.

\section{Az anyai kötődés és az iskolai kötődés koherenciája}

A pilotkutatás első részében az anyához való kötődés intenzitása került fókuszba, míg a második részben, ahogyan az föntebb olvasható, az iskolához való kötődés erősségének feltárása deviáns-veszélyeztetett és nem veszélyeztetett fiatalok körében. A két területet - az anyához és az iskolához füződő viszonyt - egymás tükrében is érdemes megvizsgálni. Az anyai kötődés és az iskolai kötődés összefüggéseit az alábbiakban foglalom össze.

A két teszt kérdéseire adott tanulói válaszok mátrixa összesítve - tehát csoportbeli hovatartozásra való tekintet nélkül - az alábbi ábrán láthatóak.

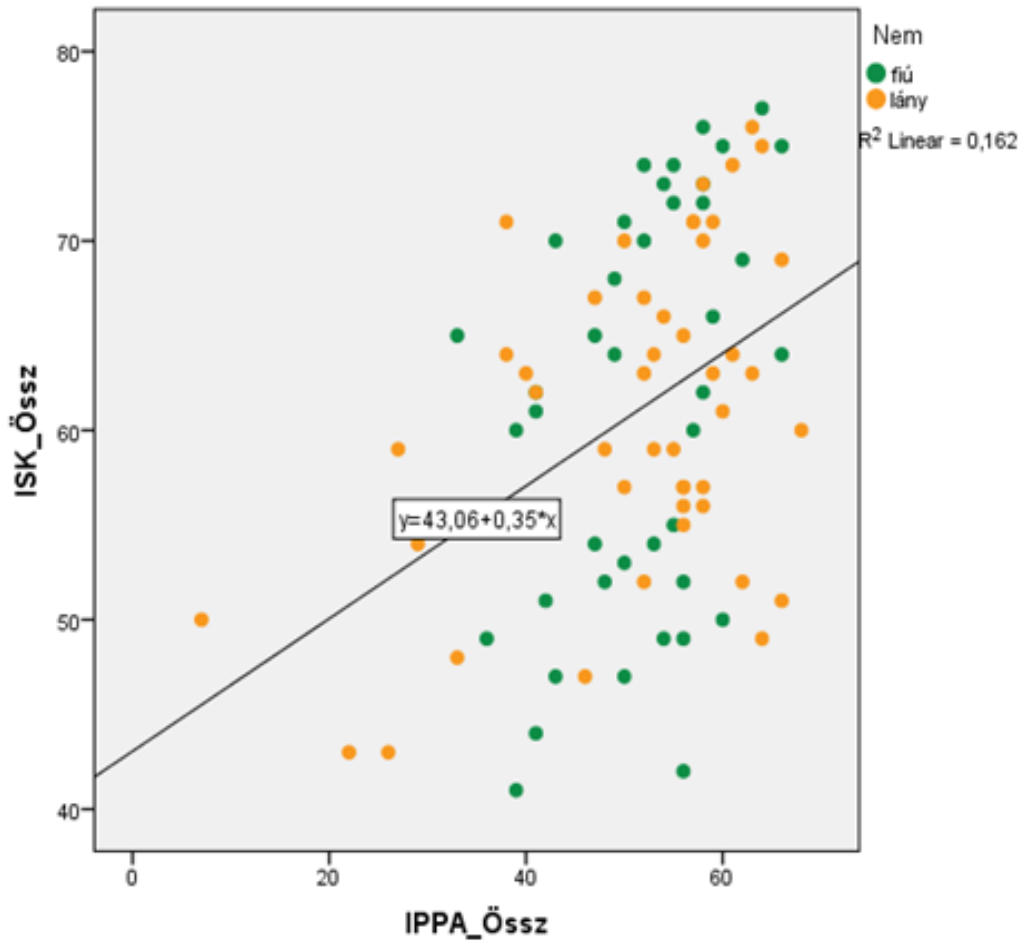

3. ábra: Az anyai és az iskolai kötődés összefüggései 
A korreláció szignifikáns a teljes mintában, melynek erőssége 0,402, a vizsgálati csoportot önmagában vizsgálva azonban még erősebb a kapcsolat: 0,478. Ezek az értékek mindkét esetben lineáris, pozitív összefüggést mutatnak, melyre utal a lineáris regressziós egyenes egyenlete is. Mind a konstans tag, mind a regressziós együttható 0-tól való eltérése igazolható 95\%-os megbízhatósági szinten t-próbával.

Tulajdonképpen tehát az állapítható meg a statisztikai adatok alapján, hogy pozitív összefüggés mutatkozik az iskolai kötődés és az anyai kötődés között. Tehát az a válaszadó, aki magas pontszámot adott összességében az anyához való kötődést mérő tesztre, átlagosan magas pontszámot fog adni az iskolai kötődést mérő tesztre is. Az egyik teszt válaszainak ismeretében következtethetünk tehát a másik tesztre adandó válaszokra is.

$A z$ iskolai és az anyai kötődés erősségének pozitív kapcsolatát a belső munkamodell elképzelésre alapoztam. Bowlby úgy vélte, hogy a belső munkamodell egy mentális norma, amely tulajdonképpen azt jelenti, hogy a gyermek olyan kötődést fog kialakítani minden számára közeli személlyel, mint amilyet a gondozójával.

A statisztikai adatok alapján az állapítható meg, hogy szoros összefüggés van az anyai és az iskolai kötődés erőssége között. Ez az összefüggés dolgozatom kardinális kérdésre is választ ad, mégpedig arra, hogy az iskola megjelenhet-e pót-kötődési tárgyként vagy másodlagos kötődési tárgyként a gyerekek életében. A pozitív korreláció arra jelent magyarázatot, hogy pót-kötődési tárgyként nem funkcionál az iskola, hiszen ahhoz negatív összefüggésre lenne szükség az anyai és az iskolai kötődést illetően, azonban a másodlagos kötődési tárgy - illetve a pedagógusok esetében a másodlagos kötődési személy - funkcióját betöltheti és az adott vizsgálatban be is tölti az iskola, ezzel párhuzamosan pedig az iskola védőfaktor szerepe is megjelenik. Tehát az iskola kizárólagossága nem állapítható meg, azonban másodlagossága mindenképp.

A pozitív korrelációra is magyarázatként szolgálhat Bowlby elképzelése a belső munkamodellről. A munkamodell az anya-gyermek kontextusban fejlődik ki és alapját képezi a kötődési viselkedés szituációkon keresztüli stabilitásának. A belső munkamodellek tehát önmagunkra és legfontosabb kapcsolati partnereinkre vonatkoznak. A fentiek ismeretében tehát hipotézisem igazolható.

\section{Az eredmények megvitatása}

A pedagógusok felelőssége a kötődés aspektusából megközelítve is rendkívül nagy. A tanárok, tanítók a gyermekek alapvető kötődési jellegzetességeit transzformálhatják pozitívabb irányba a megfelelő érzékenységgel és odafigyeléssel, tehát képesek lehetnek jelentős mértékben kompenzálni és kiegészíteni azokat a hiányosságokat, amikből a gyermek felépítette a saját belső munkamodelljét.

$A z$ iskola védőfaktor szerepe is kiemelten fontos, amely természetesen legnagyobb mértékben a pedagógusokon és az ő munkájukon, együttműködésükön múlik. Ha az iskola biztos bázisként van jelen a gyerekek életében, úgy a védelmező funkciója is intenzívebben müködhet.

Több kutatás is azt bizonyítja, hogy a hagyományos oktatási forma eltérő kulturális adaptációját alkalmazó iskolákban egyfelől növekszik a tanulási teljesítmény, másrészt pedig a gyerekek lelkesebben vesznek részt az iskolai elfoglaltságokon (Cole, 2006). Azt gondolom, hogy ha az iskolai körülmények közelítenek az otthon megszokottakhoz, akkor a gyerekek nagyobb eséllyel fogják biztonságban érezni magukat az iskolában, illetve a pedagógusokhoz füződő kapcsolatuk is szorosabbá válhat. Így hatványozódhat az iskola védőfaktor szerepe és, a pedagógus mint másodlagos kötődési személy szerepe a gyerekek életében. 


\section{Felhasznált irodalom}

Andorka Rudolf és Harcsa István (1990): Deviáns viselkedés. In: Andorka, Kolosi és Vulkovich (szerk.) Társadalmi riport.TÁRKI, Budapest, 217-227.

Cassidy, J. és Shaver, P. R. (1999, szerk.): Handbook of Attachment. Guilford Press, New York.

Cole, M. és Cole, S. R. (2006): Fejlődéslélektan. Osiris Kiadó, Budapest.

F. Lassú Zsuzsa (2011): Kötődés és változatai a szülő mentális sérülékenységének kontextusában. In: F. Lassú Zsuzsa (szerk.) Gyermekek mentálisan sérülékeny családokban. ELTE Eötvös Kiadó, Budapest, 51-75.

Hirschi, T. (1969): Causes of Deliquency. University of Calofornia Press. Berkeley.

Inántsy-Pap Judit (2009): Kötődés és kortárskapcsolatok az óvodáskorban. Faculty of Central European Studies, Constantine the Philosopher University Nyitra; Kocka Kör, Debrecen.

Nász Barbara (2015): A deviáns veszélyeztetettség és az anyai kötődés kapcsolata Gyermeknevelés, 3 2. sz. 15-28.

Szabó Éva és Virányi Barbara (2011): Az iskolai kötődés jelentősége és vizsgálata. Magyar Pedagógia, 111. 2. sz. 111-125.

Pikó Bettina (2011): A deviáns magatartás értelmezési keretei a biopszichoszociális elmélet tükrében. In: Pikó Bettina (szerk.) A deviáns magatartás szociológiai alapjai és megjelenési formái a modern társadalomban. JATE Press, Szeged, 9-16. 